\title{
Impact of Foreign Direct Investment and Barriers to MNC Supply Chain Integration in Vietnam
}

\author{
Hamdi Bilici* \\ Loi Ta ${ }^{\text {** }}$ \\ Briant Carcamo ${ }^{\text {**** }}$
}

\begin{abstract}
The Vietnamese economy has been progressing to become a supplier to many multinational corporations (MNC). However, barriers presently exist that prevent Vietnamese firms from fully integrating into the supply chain of these global actors. Weak FDI overflow and block trading has government officials and business executives troubled that Vietnamese firms are still on the periphery of these global supply networks. Even as MNCs operating in Vietnam import many semi-finished products from other countries, Vietnamese firms are not benefiting from the opportunities to incorporate into the supply chain because of the lack of global experience, FDI, an educated workforce and outdated facilities. Vietnamese firms must upgrade their facilities and equip their labor forces to acquire MNC contracts and find global partners who can supply financing and knowhow.
\end{abstract}

Keywords: FDI theory of OLI, supply chain management, multinational company, spillover of FDI, impact of FDI

JEL Classification: F4, F6, F65

\section{Introduction}

This paper studies the recent economic developments to show the impact of Foreign Direct Investment (FDI) into Vietnamese company's integration into the supply chain of Multi-National Companies (MNC).

\footnotetext{
* Hamdi Bilici is at California State University, California, USA.

** Loi Ta is at Department of International Business, National Economics University, Vietnam.

${ }^{* * * *}$ Briant Carcamo is at Steadfast Management Company, California, USA.
} 
Over the last 30 years, Vietnam has been the recipient of over \$240 Billion in FDI with the goal of integrating Vietnamese firms into global supply chains. FDI alone makes up $18 \%$ of GDP, $46.3 \%$ of total industrial GDP, and comprises $66.2 \%$ of Vietnam's exports. FDI from MNCs is strategically important for Vietnam as it tries to vie capital from Samsung, Canon, Toyota, and Honda. However, investor expectations have not been fully realized and the spillover from FDI has been lower than expected. Structural barriers like low levels of manufacturing technology and skilled work has kept Vietnamese firms on the periphery of these global supply networks.

\section{Research Objective}

This paper will 1) review the supply chain requirements of select MNCs operating in Vietnam to understand the challenges in outsourcing management; 2) to analyze the challenges of Vietnamese firms' ability to join global supply chains through the OLI Framework of FDI; and 3) to make recommendations that would promote MNC and Vietnamese firm integration into global supply chains.

\section{Existing Research}

Supply chain management (SCM) does not just encompass the management of the practical organizational functions of a firm. The term is also not a description of supplier partnerships nor does it encompass the logistics functions of a firm. Instead, SCM represents the merging of supply chain strategy with overall business strategy. In evaluating business strategy, MNCs evaluate suppliers in their ability to not just provide the inputs in the value chain, but to also coordinate logistics and management processes. As such, SCM extends beyond logistics but rather it involves the myriad decisions within and between organizations in the supply chain. Managers need to analyze both competitive business strategy as well as individual suppliers in a chain to enhance value in effective SCM. Supply chain management also leverages strategic points in supply chain functions to enhance competitive strategy. SCM is not the additive functions of logistics, purchasing, operations, and marketing nor is it the utility of individual companies in the chain. SCM is a tool to understand the links and resources available at every part of the value chain. Research suggests that supply chains will be growing increasingly globally. $90 \%$ of global demand is not fully met by local supply and only $25 \%$ of that demand was met by MNCs. As such, supply chains need to become $43 \%$ more global in the next decade just to maintain a firm's competitive edge.

There are many approaches have resulted in the combinations of qualitative and quantitative analysis, although it is not clear if systems level analysis has been empir- 
ically proven as effective. C.M. Harland's research on chains, networks, and relationships of supply chains concluded that although there are differences in approaches to SCM, the performances of supplier networks did not differ significantly (Harland, 1996). As such, SCM frameworks are a topic that is still widely researched.

In Vietnam, there is little research on Vietnamese firm's ability to join MNC value chains. Until now, Vietnamese firms have had little bargaining power to incorporate into many global supply chains, although the country does participate in a limited way in MNCs like Toyota and Canon. Nguyen Phi Lan researched the relationship between FDI and local economic growth and found that there was a significant impact and recommended that Vietnamese open their economy more to foreign investment (Lan, 2006). FDI technology spillover benefits Vietnam both vertically and horizontally (Le \& Pomfret, 2010). The increase in investment and spillover expected from FDI impacts industry vis a vis direct and indirect channels in Vietnam, ultimately leading to productivity growth, export promotion, and economic restructuring. However, research suggests that FDI spillover from exports in manufacturing and processing industries may not be occurring at the expected levels. There are several elements that prevent Vietnam from maximizing the benefits of FDI spillover (Ngoc, 2016).

\section{Hypothesis, Model and Methodology}

Our research will test that hypothesis that there should be more participation by Vietnamese firms in MNC supply chain if FDI increases in Vietnam. Higher levels of FDI should support supply chain integration effects. If no such correlation exists, this paper will analyze barriers to integration.

Data is collected from two main sources: 1) Vietnamese Firms Investigation from 2001-2003, obtained from the Statistics Department of Vietnam, and 2) Provincial Competitiveness Index (PCI) of Vietnam from 2005 - 2015, published by the Chamber of Commerce and Industry of Vietnam (2015).

\section{Research Model}

Figure 1. The Model

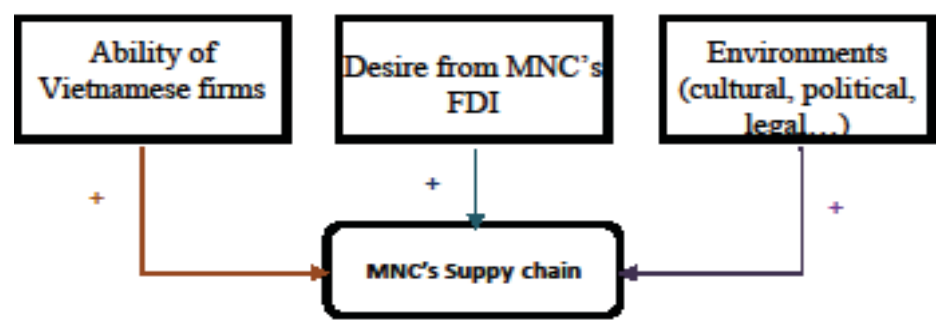


Independent variables VN Ability, MNC's FDI desire and Environment that lead to changing of MNC's Supply chain in Vietnam.

$$
\begin{gathered}
\text { MNC's Supply Chain }_{j t}=f\left(\text { VN Ability }_{i j t}, \text { MNC's FDI Desire }_{i j t} \text { ' }^{\text {Environment }}{ }_{i j t}, \mu_{i j t}\right)
\end{gathered}
$$

Definition of Variables:

MNC's Supply Chain is the Vietnamese firm participating in the MNC's supply chain

$\boldsymbol{V N}$ Ability the ability for the Vietnamese firm to meet the MNC's work requirement

MNC's FDI Desire represents the interest by MNCs to utilize Vietnamese vendors

Environment represents the cultural, legal, or political environment factor in Vietnam

Analysis of Vietnamese Firms' Ability to Join in Supply Chain of MNC's in Vietnam

In analyzing the export structure of Vietnam, the exports have been moving away from raw materials to semi to fully-finished products over the years, which suggests that firms are integrating into global supply chains.

Table 1: Export structure of Vietnamese goods (2005-2012)

\begin{tabular}{|l|l|l|l|l|l|l|}
\hline Fields & 2005 & 2008 & 2009 & 2010 & 2011 & $\mathbf{2 0 1 2}$ \\
\hline Portion & 100,0 & 100,0 & 100,0 & 100,0 & 100,0 & 100,0 \\
\hline Raw material & 49,7 & 44,2 & 39,0 & 34,8 & 34.8 & 30,7 \\
\hline Foodstuff or live animals & 19,5 & 19,4 & 20,2 & 18,6 & 18,0 & 16,4 \\
\hline $\begin{array}{l}\text { Tobacco or drinks } \\
\text { material }\end{array}$ & 0,5 & 0,3 & 0,4 & 0,4 & 0,4 & 0,4 \\
\hline Other materials & 3,8 & 4,0 & 3,4 & 4,7 & 4,9 & 3,7 \\
\hline Crude fuels & 25,8 & 20,3 & 14,9 & 11,0 & 11,3 & 9,9 \\
\hline Other fuels & 0,1 & 0,2 & 0,1 & 0,1 & 0,2 & 0,3 \\
\hline $\begin{array}{l}\text { Semi or fully finished } \\
\text { products }\end{array}$ & $\mathbf{5 0 , 3}$ & $\mathbf{5 5 , 2}$ & $\mathbf{5 9 , 6}$ & 65,1 & $\mathbf{6 5 , 1}$ & $\mathbf{6 9 , 2}$ \\
\hline
\end{tabular}

Source: Statistic Department of Vietnam, 2013

For example, Samsung's $\$ 10$ billion investment in manufacturing made Vietnam the biggest smart phone export center in the world, creating \$28.5 billion in exports in 2014 . 
In 2012, FDI block had an export surplus of $\$ 4.099$ billion while the Vietnamese experienced a trade deficit of $\$ 2$ billion. In 2013, FDI took $60 \%$ of total foreign trade from Vietnam. From the Vietnamese perspective, FDI investments are expected to have spillover effects whereby Vietnamese firms receive experience from MNCs as investments increase. However, the trade deficit suggests that Vietnamese are not benefiting from MNCs experience in global markets and still stand outside of the MNC supply chain.

To analyze MNC's FDI Desire, we turn to the number of firms that received FDI investments:

Table 2: Number of Vietnamese firms by size of employee and capital in 2011

\begin{tabular}{|c|c|c|c|c|c|c|c|c|}
\hline \multirow[t]{3}{*}{ Field of business } & \multicolumn{4}{|c|}{ Small \& Medium enterprises } & \multicolumn{4}{|c|}{ Big size enterprises } \\
\hline & \multicolumn{2}{|c|}{$\begin{array}{l}\text { By size } \\
\text { employee }\end{array}$} & \multicolumn{2}{|c|}{ By size of capital } & \multicolumn{2}{|c|}{$\begin{array}{l}\text { By size of } \\
\text { employee }\end{array}$} & \multicolumn{2}{|c|}{ By size of capital } \\
\hline & No. & $(\%)$ & & $(\%)$ & No. & $(\%)$ & No. & $(\%)$ \\
\hline Total & 316.941 & 100,0 & 309.322 & 100,0 & 7.750 & 100,0 & 15.369 & 100,0 \\
\hline $\begin{array}{l}\text { Agriculture, forest and } \\
\text { sea foods }\end{array}$ & 3.197 & 1,01 & 3.113 & 1,01 & 111 & 1,43 & 195 & 1,27 \\
\hline $\begin{array}{l}\text { Industry } \\
\text { construction }\end{array}$ & 97.415 & 30,7 & 95.458 & 30,9 & 3.873 & 50,0 & 5.830 & 37,9 \\
\hline Services & 216.329 & 68,3 & 210.750 & 68,1 & 3.766 & 48,6 & 9.340 & 60,8 \\
\hline
\end{tabular}

Source: Statistic Department of Vietnam, 2013

The data in table 2 shows that most Vietnamese enterprises are in the service fields such as tourism, restaurant, consulting, banking, transportation, etc. versus manufacturing fields such as mechanics, plastics, chemical, and so on. As such, MNCs may struggle to find value vendors to make spare parts as many Vietnamese firms do not manufacture goods.

Looking at the automobile manufacturing sector for example, the data confirms that Vietnamese do not meet the requirements to join global supply chains. Toyota, the largest MNC in Vietnam, only accepted 7\% of total components supplied by Vietnamese firms, while the rest was imported by other suppliers abroad.

The reasons why components are not accepted are varied and reports state that $30 \%$ of the firms surveyed do not get information necessary to compete and $70 \%$ do not meet technical requirements. However, when surveying firms' interest in joining the MNCs supply chain, $67 \%$ have an expectation to join, $29 \%$ have no idea, and $4 \%$ would not be interested in joining. 


\section{OLI Theory}

The OLI approach to FDI identifies three potential advantages why a firm may choose to become multinational: Ownership, Location, and Internalization advantages (Dunning, 1988). Ownership suggest that successful MNCs have firm-specific advantages that allow it to overcome the costs of expanding to a foreign country. Location advantages answers the question of whether it seeks lower production costs (vertical FDI) or access to the market (horizontal FDI). Internalization advantages influences how firms choose to operate in foreign country, exchanging savings in transactions of a wholly-owned subsidiary against the advantages of other entry modes such as exports, licensing, or joint venture. As such, MNCs make a choice to engage in FDI when the firm can expect the realization of these advantages, per the following table:

Table 3: OLI Theory in form of market entry

\begin{tabular}{|l|l|l|l|l|}
\hline \multirow{2}{*}{$\begin{array}{l}\text { Form of } \\
\text { market entry }\end{array}$} & \multicolumn{2}{|l|}{ Categories of advantages } \\
\cline { 2 - 5 } & $\begin{array}{l}\text { Ownership } \\
\text { advantages }\end{array}$ & $\begin{array}{l}\text { Internalization } \\
\text { advantages }\end{array}$ & $\begin{array}{l}\text { Location } \\
\text { advantages }\end{array}$ \\
Licensing & Yes & No & No \\
\hline Investor's decision & Export & Yes & Yes & No \\
\cline { 2 - 5 } & FDI & Yes & Yes & Yes \\
\hline
\end{tabular}

Source: Dunning (1981)

Three basic forms of international activities of companies can be distinguished: Export, FDI and Licensing. The term net ownership advantages is used to express the advantages that a company has in foreign and unknown markets. While resource seeking investments are made in order to establish access to basic material like raw materials or other input factors, market seeking investments are made to enter an existing market or establish a new market. A closer distinction is made by Dunning with the terms efficiency seeking investments, strategic seeking investments and support investments.

In Vietnam, MNCs can get ownership and internalization advantages, but firms that seek a cheaper skilled labor force will not achieve location advantages due to the gap in skilled labor. 
Table 4: Labor force from 16 years ages by education and skills (in 000)

\begin{tabular}{|l|l|l|l|l|}
\hline Criteria & $\begin{array}{l}\text { Quarter 3 in } \\
\mathbf{2 0 1 3}\end{array}$ & $\begin{array}{l}\text { Quarter 4 in } \\
\mathbf{2 0 1 3}\end{array}$ & $\begin{array}{l}\text { Quarter 1 in } \\
\mathbf{2 0 1 4}\end{array}$ & $\begin{array}{l}\text { Quarter 2 in } \\
\mathbf{2 0 1 4}\end{array}$ \\
\hline 1. uneducated and unskilled & $43.956,7$ & $43.726,4$ & $43.528,0$ & $43.760,2$ \\
\hline 2. educated jobs & $2.831,1$ & $2.850,8$ & $2.678,7$ & $2.562,3$ \\
\hline 3.Special educational skills & $1.981,7$ & $2.033,4$ & $2.009,3$ & $1.971,0$ \\
\hline 4. collage education & $1.135,7$ & $1.121,1$ & $1.211,0$ & $1.148,5$ \\
\hline 5. Bachelor education & $3.848,4$ & $3.865,7$ & $4.037,6$ & $4.123,4$ \\
\hline 6. unidentified & 102,3 & 101,5 & 116,3 & 149,2 \\
\hline 7.Total & $\mathbf{5 3 8 5 5 , 9}$ & $\mathbf{5 3 6 9 8 , 9}$ & $\mathbf{5 3 5 8 0 , 9}$ & $\mathbf{5 3 7 1 4 , 5}$ \\
\hline
\end{tabular}

Source: Statistic Department of Vietnam, 2014

Most employees fall under unskilled labor. MNCs struggle to recruit skilled labor at low wages unlike other countries like Taiwan or China. However, there is an expectation that Vietnam will achieve similar levels over the next 4 or 5 years to get more skilled labor.

Aside from the skilled labor shortage, Vietnam is also weak in the technology component as it relates to manufacturing.

Figure 2: Toyota automobile production schema

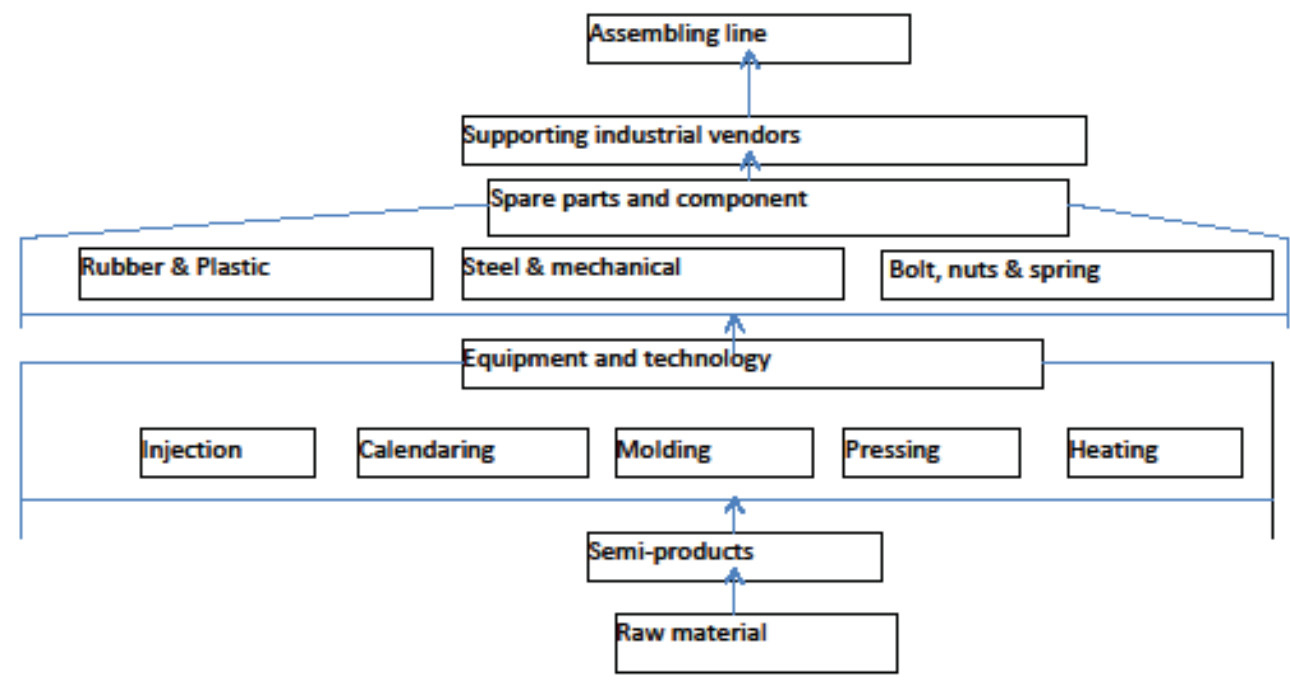

After revealing the requirement in making car components in 2010, Toyota only received 30 Vietnamese firms to supply plastic, rubber and mechanical steel but only 3 of them meet Toyota requirements. Toyota only accepted $7 \%$ of the total components instead of the $40 \%$ commitment. The Ministry of Finance pressured Toyota to 
accepting the components by proposing to cancel tax exemptions. Unless Toyota can find reliable and qualified vendors in its supply chain, Toyota will seek part manufacturers elsewhere.

\section{Analysis}

The results from testing independent variables to MNCs supply chain in Vietnam are summarized in Table 5 and Table 6.

The Vietnamese Chamber of Commerce and Industry launches an annual survey called the Provincial Competitive Index (PCI) to receive feedback from industry leaders and to improve the country's business environment. It consists of 96 questions and 24 categories.

Table 5: Analysis on environment factors based on PCI in Vietnam

\begin{tabular}{|l|l|l|l|l|l|}
\hline $\begin{array}{l}\text { Fixed-effects (within) regression } \\
\text { Group variable: id environment }\end{array}$ & \multicolumn{1}{l}{$\begin{array}{l}\text { Number of obs }= \\
\text { Number of groups }=\end{array}$} \\
\hline MNC's Supply chain__ & Coef. & Std. Err. & t & P >ltl & [95\% Conf. Interval] \\
\hline Pci- manufacturing_ & $-3.29 \mathrm{e}+08$ & $1.90 \mathrm{e}+08$ & -1.73 & 0.097 & $-7.21 \mathrm{e}+086.40 \mathrm{e}+07$ \\
\hline _cons & $2.22 \mathrm{e}+10$ & $1.23 \mathrm{e}+10$ & 1.81 & 0.084 & $-3.23 \mathrm{e}+094.76 \mathrm{e}+10$ \\
\hline sigma_u & $1.054 \mathrm{e}+09$ & & & \\
\hline sigma_e & $1.857 \mathrm{e}+09$ &
\end{tabular}

Source: Ngoc (2016)

The $\mathrm{P}_{-}$value $>0.05$ that environment factors are not significant for Vietnamese firms joining MNC's Supply chain in Vietnam.

To test for significance the ability of Vietnamese firms to enter into manufacturing and processing supply chains, Vietnamese exports in manufacturing and processing industries were regressed against the PCI Index:

Table 6: Analysis on VN ability based on PCI in Vietnam

\begin{tabular}{|c|c|c|c|c|c|}
\hline \multirow{2}{*}{\multicolumn{2}{|c|}{$\begin{array}{l}\text { Fixed-effects (within) regression } \\
\text { Group variable: id VN ability }\end{array}$}} & \multirow{2}{*}{\multicolumn{2}{|c|}{$\begin{array}{l}\text { Number of obs }= \\
\text { Number of groups }=\end{array}$}} & \multirow{2}{*}{\multicolumn{2}{|c|}{$\begin{array}{l}96 \\
24\end{array}$}} \\
\hline & & & & & \\
\hline MNC's Supply chain_ & Coef. & Std. Err. & $\mathrm{t}$ & $\mathrm{P}>|\mathrm{t}|$ & [95\% Conf. Interval] \\
\hline VN_ability_ & -9971.203 & 2841.538 & -3.51 & 0.002 & $-15849.37-4093.033$ \\
\hline _cons & $1.57 \mathrm{e}+09$ & $3.30 \mathrm{e}+08$ & 4.75 & 0.000 & $8.86 \mathrm{e}+08 \quad 2.25 \mathrm{e}+09$ \\
\hline sigma_u & \multicolumn{5}{|l|}{$2.120 \mathrm{e}+09$} \\
\hline sigma_e & \multicolumn{5}{|l|}{$1.459 \mathrm{e}+09$} \\
\hline rho & \multicolumn{5}{|c|}{67851719 (fraction of variance due to $\mathrm{u} \_\mathrm{i}$ ) } \\
\hline
\end{tabular}

Source: Ngoc (2016) 
The $\mathrm{P}=$ value $<0.05$ means that $\mathrm{VN}$ ability plays a significant factor on whether the firm can join the global supply chain in Vietnam.

As for Firm Desire to partner with a Vietnamese firm, FDI desire and FDI investment in the manufacturing industry was regressed to MNCs supply chain exports:

Table 7: Analysis of MNC'FDI desire in Vietnam

\begin{tabular}{|c|c|c|c|c|c|c|c|}
\hline \multirow{2}{*}{\multicolumn{2}{|c|}{$\begin{array}{l}\text { Fixed-effects (within) regression } \\
\text { Group variable: id MNC's FDI desire }\end{array}$}} & \multirow{2}{*}{\multicolumn{3}{|c|}{$\begin{array}{l}\text { Number of obs } \\
\text { Number of groups }\end{array}$}} & \multicolumn{3}{|c|}{24} \\
\hline & & & & & $=$ & 6 & \\
\hline MNC's supply chain_ & Coef. & Std. Err. & $\mathrm{t}$ & $\mathrm{P}>|\mathrm{t}|$ & & & [95\% Conf. Interval] \\
\hline fdi_Industry_ & 177.2588 & 67.62168 & 2.62 & 0.047 & & & $3.431686 \quad 351.0858$ \\
\hline MNC's FDI desire_ & -26212.15 & 6513.64 & -4.02 & 0.010 & -42955.99 & -9468.3 & $-42955.99 \quad-9468.3$ \\
\hline _cons & $6.54 \mathrm{e}+09$ & $1.42 \mathrm{e}+10$ & 0.46 & 0.664 & & & $-2.99 e+10$ \\
\hline sigma_u & $7.882 \mathrm{e}+08$ & & & & & & \\
\hline sigma_e & $9.491 \mathrm{e}+08$ & & & & & & \\
\hline rho & .40815038 & (fraction of & arianc & due to $\mathrm{c}$ & & & \\
\hline
\end{tabular}

Source: Ngoc (2016)

The low $\mathrm{p}$ value means that both factors had an impact on MNCs supply chain integration in Vietnam. Although willingness is significant, the ability for firms to perform is still too weak.

According to table, we can see that P-value $<0.05$ that means this factor also has an impact on MNC's Supply chain in Vietnam. Their desire is too much while Vietnamese firm ability is still too weak.

When all factors are regressed together, the model reveals that firm ability and MNC FDI desire play significant roles whether firms will incorporate into the value chain:

Table 8: Analysis of three elements to MNC's supply chain management in Vietnam

\begin{tabular}{|c|c|c|c|c|c|}
\hline \multirow{2}{*}{\multicolumn{2}{|c|}{$\begin{array}{l}\text { Fixed-effects (within) regression } \\
\text { Group variable: idSCM }\end{array}$}} & \multirow{2}{*}{\multicolumn{2}{|c|}{$\begin{array}{l}\text { Number of obs } \\
\text { Number of groups }\end{array}$}} & \multicolumn{2}{|l|}{96} \\
\hline & & & & 24 & \\
\hline MNC's supply chain_ & Coef. & Std. Err. & $\mathrm{t}$ & $\mathrm{P}>|\mathrm{t}|$ & [95\% Conf. Interval] \\
\hline VN firm ability_ & 146.5501 & 67.3811 & 2.17 & 0.040 & $7.161724 \quad 285.9386$ \\
\hline MNC's FDI desire_ & -34851.16 & 8113.867 & -4.30 & 0.000 & $-51635.97-18066.35$ \\
\hline Pci_environment_ & $-3.59 e+08$ & $1.89 \mathrm{e}+08$ & -1.90 & 0.070 & $-7.49 e+08 \quad 3.16 e+07$ \\
\hline _cons & $2.46 e+10$ & $1.22 \mathrm{e}+10$ & 2.02 & 0.056 & $-6.45 e+08 \quad 4.98 e+10$ \\
\hline sigma_u & $1.210 \mathrm{e}+09$ & & & & \\
\hline sigma_e & $1.768 \mathrm{e}+09$ & & & & \\
\hline rho & .31886447 & on of varian & to $\mathrm{u} \_\mathrm{i}$ ) & & \\
\hline
\end{tabular}

Source: Ngoc (2016)

However, the PCI Environment index is not statistically significant. The index only represents how attractive a province may be relative to others but overall, the 
PCI index does not seem to contribute to the integration of firms into the supply chain.

\section{Conclusions and Recommendations}

Vietnamese firms face three major problems as it relates to supply chain integration: capital, skilled labor (both worker and manager level) and technology. These issues are preventing the integration of Vietnamese firms into active supplier network of the world's largest firms. As such, the Vietnamese government can implement policies to encourage firm activity: financing for Vietnamese firms participating in MNCs supply chain and invest in developing human capital.

\section{Financing Opportunities}

Most Vietnamese firms have low levels of capital, which makes it difficult to compete with rivals from China, Taiwan, and Thailand. This is partly due to the Vietnamese banking system. The banking system acts as a state bank as it interferes in setting interest rates and rules. The largest 4 commercial banks in Vietnam (Vietcombank, Agribank, BIDV, and Vietinbank) are heavily influenced by political forces and often ignore market driven sentiments. For example, in 2008, the Vietnamese state bank leader confused CPI with an inflation index, which raised interest rates up to $18 \%$ that cost VND 36 Billion. Many firms went bankrupt from 2008 to 2012. The central bank should implement a system to buy bad debt and sell it in the secondary market, while applying clearing methods for these special cases. This will help to free up capital and promote business development. Additionally, making a fund for Vietnamese firms already in MNC supply chains will help them renew equipment, technology, and increase human capital in this competitive space.

\section{Developing Human Capital}

More than $81 \%$ of the labor force in Vietnam lacks the necessary skills or education. Specialty or technical engineers need to be trained by working in MNCs plants abroad so that they can return to Vietnam to create products that meet MNCs technical requirements. Financial to technical employees should be available so that they can create new owned business, or to encourage them to expand existing businesses. Allowing for tax exemption to technology expenses may incentivize firms to innovate. 


\section{REFERENCES}

Dunning, J. H. (1988). The eclectic paradigm of international production: A restatement and some possible extensions. Journal of International Business, 1-31.

Harland, C. M. (1996). Supply Chain Management: Relationships, Chains and Networks. British Journal of Management, S63-S80.

Lan, N. P. (2006). Foreign Direct Investment and its Linkeage to Economic Growth In Vietnam: A Provincial Level Analysis. Centre for Regulation and Market Analysis. Adelaid, Austrlia: University of South Austrailia.

Le, Q. H., \& Pomfret, R. (2010, August). Foreign Direct Investment and Wage Spillovers in Vietnam: Evidence from Firm Level Data. ASEAN Economic Bulleting, p. 14.

Ngoc, T. L. (2016). FDI spillover in Vietnamese exports in the manufacturing and processing industries. National Economics University of Hanoi. 